\title{
The oldest "intermetamorphic" larva of an achelatan lobster from the Lower Jurassic Posidonia Shale, South Germany
}

Joachim T. Haug, Carolin Haug, and Günter Schweigert

Acta Palaeontologica Polonica 64 (4), 2019: 685-692 doi:https://doi.org/10.4202/app.00627.2019

Achelatan lobsters, also known as spiny and slipper lobsters, develop via a highly specialised larval form. This special larva, phyllosoma, is flat, translucent, possesses elongate legs and can grow to enormous sizes. Although these larvae may appear very fragile, they are well-known as fossils. Thousands of specimens have been found in the lithographic limestone of Southern Germany (Tithonian, Upper Jurassic, about 150 mya). At least three types of fossil, but modern-appearing phyllosoma larvae are known. Additionally, fossil larvae that possess only some of the characters of modern-day phyllosoma larvae are known from the same Lagerstätte, but also from the younger limestone beds of Lebanon. Here we report a new achelatan fossil from the older Posidonia Shale (Toarcian, Lower Jurassic, 175-183 mya). The specimen shows certain characters of a phyllosoma larva, but other characters appear like those of post-phyllosoma stages of achelatan lobsters. This specimen is therefore the oldest occurrence of an achelatan lobster larva. We compare the new specimen with other fossil larvae with such mixed or "intermetamorphic" morphologies.

Key words: Decapoda, Achelata, phyllosoma, zoea, Jurassic, Germany.

Joachim T. Haug [joachim.haug@palaeo-evo-devo.info] and Carolin Haug [carolin.haug@ palaeo-evo-devo.info], Ludwig Maximilians University Munich, Biocenter, Großhaderner Str. 2, 82152

Planegg-Martinsried, Germany and GeoBio-Center at LMU, Richard-Wagner-Str. 10, 80333 München, Germany. Günter Schweigert [guenter.schweigert@smns-bw.de] State Museum of Natural History Stuttgart, Rosenstein 1, 70191 Stuttgart, Germany.

This is an open-access article distributed under the terms of the Creative Commons Attribution License (for details please see creativecommons.org), which permits unrestricted use, 
distribution, and reproduction in any medium, provided the original author and source are credited.

Fof Full text $(635.5 \mathrm{kB})$ 